\title{
Plastic Waste as an Alternate Fuel
}

\author{
Manoj Suthar ${ }^{(1)}$, Nandeshwar Lata ${ }^{(2)}$, Bharat Nagar ${ }^{(3)}$ \\ ${ }^{1}$ M.tech scholar, ${ }^{2}$ Assistant Professor, ${ }^{3}$ Professor, \\ Department of Environment Engineering, Jagannath University Chaksu, \\ Rajasthan, India
}

\begin{abstract}
In this study, issues of plastic waste to land and sea water and alternate mitigation measures were studied of plastic waste for excess generation of the plastic waste which created opportunity to meet industrial energy demand. In this study it is identified that on land dumping of plastic waste causes negative impact on soil quality. On dump site of plastic waste phosphorous and potassium was found to be higher from normal soil samples which shows the depletion of nutritional quality of dumpsite soil due to dumping of waste. There was no significant difference in level of heavy metals in sea water samples as seen in case of soil samples. This may be due to dilution factor because of rainfall, high tide low tide, and wind speed and sea bottom current.

To identify the energy opportunity from plastic waste, different type of recycle plastics numbers from 1 to 7 were analysed and a range of gross calorific value obtain in range of $5500 \mathrm{kCal} / \mathrm{kg}$ to $11500 \mathrm{kCal} / \mathrm{kg}$. This result indicates that plastic waste potential energy is fall in same range as pet coke (approx. $8500 \mathrm{kCal} / \mathrm{kg}$ ) and coal (approx. $4500 \mathrm{kCal} / \mathrm{kg}$ ). The gross calorific value of plastic waste indicates a possible solution of energy demand alternate in compare to the pet coke. The utilization of this plastic is tried in cement plant by the method of co-processing as an alternate fuel. The quantity of fuel, plastic and clinker produces with and without plastic waste identified throughout the process. Specific heat through co-processing shows that with fuel (plastic waste+ Pet coke) specific heat for clinkerization increases around $755 \mathrm{kCal} / \mathrm{kg}$ of clinker as compared without plastic waste as fuel (Only Pet coke) 753 $\mathrm{kCal} / \mathrm{kg}$ of clinker. The resultant calculation of specific heat shows no detrimental change in the heat requirement means clinkerization is performed very well. This heat requirement not that much altered which signifies a scope as alternate fuel which can be utilized in mix of pet coke.

During co-processing stack emission was also monitored and this indicates no major changes and emission is within limit. Dioxin \& Furan as harmful gases emission concentration was 0.019 ngTEQ/Nm3 as compared to standard of $0.1 \mathrm{ngTEQ} / \mathrm{Nm3}$.
\end{abstract}

Key Words: Co-processing, Specific heat, recycle number, Calorific value, Plastic Waste, Dumping.

\section{INTRODUCTION}

The main purpose or motive of study is to spot alternate method for the disposal of the plastic waste so the adverse impact of plastic waste is reduced. Manufacturing industrial sectors mainly steel and cement have ample opportunity where the plastic waste is utilized as alternate fuel.

Plastic has been utilized in many forms with various applications like carry bags, industrial equipment, food packaging and etc. Due to this number of plastic waste generation has been increased in an exceedingly significant amount thanks to the rise in population and plastic consumption. The issues became rather more intense thanks to the poor degradability of general plastic.

\subsection{GLOBAL SCENARIO OF FUEL}

India is becoming world's biggest consumer of pet coke, a dark solid carbon fuel that on combustion generate $11 \%$ more greenhouse gases than coal, as per the Carnegie-Tsinghua Center in Global Policy. Plastic consumption is increasing day by day and manufacturing industry has shown indication to rise up to 22 million tons (MT) a year by 2020 from 13.4 MT in 2015 and nearly $50 \%$ of this is single-use plastic, as per Federation of Indian Chambers of Commerce. The manufacturing industrial sectors have a surge of fuel which is principally Pet coke or Coke. These fuels are having a Calorific value of approx. 7000 to $8000 \mathrm{Kcal}$ the quantity of energy requirement is to melt (change), phase of material from solid to the liquid state of material. The energy demand for this purpose is met by this fuel which is obtained from the crude oil or coal mines. Pet coke Market Segment by Applications considering rate of Consumption Growth and Market Share:

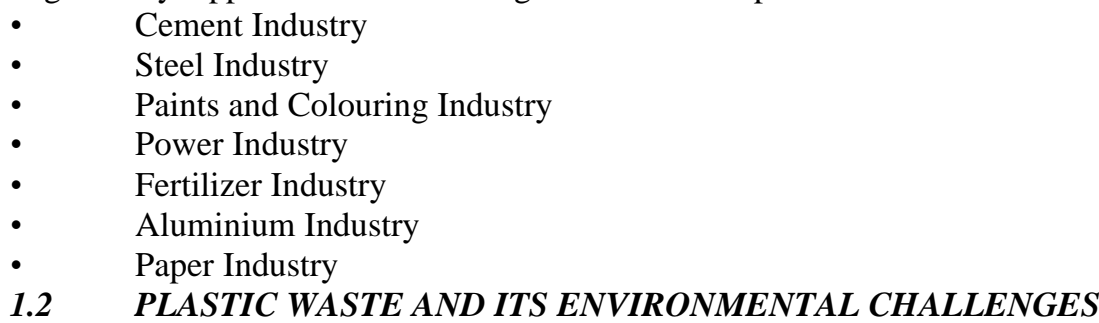

As per the MoEF\&CC plastic waste management rule describe the term as the means any plastic discarded after use or after their intended use is over. Plastic waste is slow to degrade due to its chemical structure and possess the bigger challenge of disposal. Plastic waste generates a huge amount of waste due to its large utilization in day to day activity at different stage, as it is cheap and have many benefits. 


\subsubsection{What are the reasons of release of plastic waste?}

Plastic is very cheap, easily available and its widespread use of utilization. The world population is growing as grows the urbanization. We have as mentality of disposable as comes of plastic material. The long duration of the plastic waste degradation around more than 600 years.

\subsubsection{What are the types of plastics in terms of disposal?}

1. Bio-plastic: As we know most of the plastic come from fossil fuels. Bio-plastic on other hand came from plants, example such as flex seeds. But however the impact is same as of plastic so there is no benefit in this type of plastic generation.

2. Compostable plastics: It is the next generation plastic it is made from renewable material and it is easily biodegradable while composting. It is derived from materials like corn, potato and tapioca starch, cellulose, soy protein, lactic acid. This type of plastic is non-toxic and breakdown back into carbon dioxide, water and biomass when composted. But still it requires proper composting thus still they cause the issue same of normal plastic.

3. Bio-degradable plastics: Plastics that can be easily degraded into carbon dioxide, water and biomass easily in natural condition. Some general characteristic should be there in plastic to be called as bio-degradable plastic which is as follows:

- Should not contain harmful level of heavy metals.

- Plastics should be degraded 90\% within 6 months with natural process like sunlight and hydrolysis when exposed.

- The final degraded material should not be toxic to plants.

- After 12 weeks' exposure the $90 \%$ of plastic should be degraded to a mesh size of $2 \mathrm{~mm} \times 2 \mathrm{~mm}$.

\subsection{HOW TO REDUCE THE LOAD OF PLASTIC WASTE?}

Plastic Waste Management: Plastic Waste management is an activity and action used to dispose, manage or reduce quantity of waste from generation to its final disposal. It also includes the collection, transport, treatment and disposal of plastic waste, along with monitoring and its regulation of the waste management process.

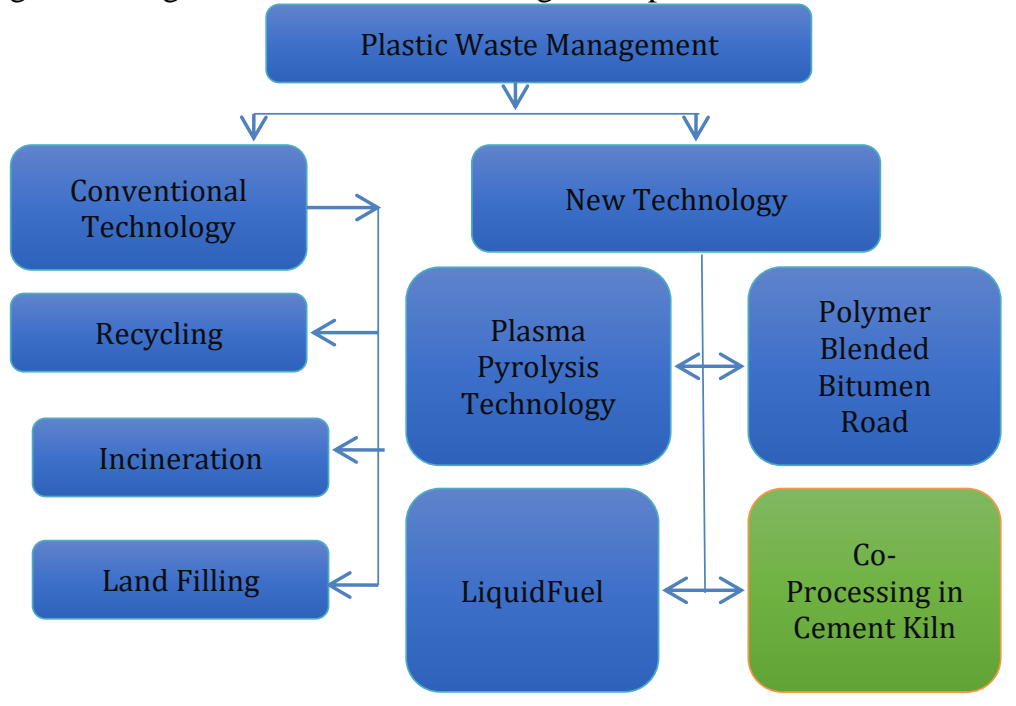

Fig. 1: Plastic Management Flowchart

A. Conventional Technology: These are the techniques as a disposable method at chemical, physical and biological level which is widely practicable to implement. This type of technology is widely used as conventional method to reduce the quantity of plastic waste.

1. Recycling: It is the process of recovering different types of plastic material to reprocess into the varied products, not to their actual form. These recycled products are made through plastic to reform to variety of products, which is mostly could not be recycled again.

2. Incineration: It is a method in which the burning of the combustible waste at high temperature to reduce the quantity of the plastic waste into ash. The heat generated may be used for the generation of the power by using boilers.

3. Landfill: Fly ash generated from the incineration process to be dumped on landfilled. In general terminology people think that landfill as dumpsites for any waste which is no use of human being, and leads to accumulation of animals and insects wandering around. In actual, landfill is a very delicate and complex structure, design and position possible in ground or above ground in which solid waste was separated from neighbouring environment.

B. New Technology: Sustainability is very difficult to maintain by management due to lots of issues. As of now the awareness of proper plastic waste disposal increases, owners and retailers are ambitious and having targets in place to grow the use of recycle material. Legislation and Governments are implementing these aspirations by implying ban on single-use plastic and raises targets for PET collection. 
1. Plasma Pyrolysis: Plasma pyrolysis is a new technology solution for converting the high calorific plastic waste into syngas by using thermal plasma. The process introduced in a non-incineration thermal process, which utilizes high temperature under oxygen deficient environment to wholly decompose fed plastic waste into syngas, carbon monoxide, hydrogen and minor amount of hydrocarbons.

2. Polymer Blended Bitumen Road: Today's scenario the waste generation as polymer waste is growing every day and there is a rise in demand which become necessity for disposal an in an environmentally sound manner. There are available solutions in practice for long which are a good solution but in return always there is an implication on environment. These methods are like landfill, incineration, plasma arc technology but still there is an alternate solution which is by adding plastic waste (polymer) into roads construction material as an eco-friendly process. The addition of plastic polymer waste with dry bitumen enhances the service characteristics of road.

3. Liquid Fuel: The oil obtains from the pyrolysis have composition from polystyrene plastic waste consists of mostly aromatic hydrocarbons, while from polypropylene, LDPE and HDPE, were majorly possesses through aliphatic hydrocarbons, as per the GC-MS. In study FTIR analysis, depicted that low density polyethylene (LDPE) and high density polyethylene (HDPE) oils had a wide match of about $96 \%$ as they have same functional groups, chemical and physical properties as of commercial diesel. Pyrolysis oil obtained from catalytic process of polystyrene resultant in more engine power, matching engine temperature, and have very low carbon monoxide and carbon dioxide emissions, as compared to un-catalysed oils and commercial fuel.

4. Co-processing of plastic waste in cement kilns as an alternate option of fuel: Co-processing of plastic wastes which is a possible alternate option to combust in cement kiln as practical and substantial solution as an environmentally disposal of plastic wastes. In cement kiln, there is variety of different kinds of hazardous and non-hazardous wastes which also includes plastic wastes under Non-Hazardous which get to utilized into Alternative Fuel and Raw materials. During the burning of all type of plastic wastes cement kiln as AFRs, the raw material and energy with high calorific value which can be fully utilized in the cement kiln as an alternate replacement of fossil materials and fossil fuels that are majorly utilized in the kiln.

\section{SCOPE OF THE STUDY}

The impact of the plastic waste landfill dumping on soil quality as comparing with the normal soil is to be identified. The impact on sea water quality on seashore due to plastic waste runoff in comparison to distant sea area. Identification of the gross calorific value of the different type of plastic waste generated and which is categorized in recycling numbers. Specific heat calculation to identify heat utilized in co-processing while using plastic waste and pet coke and without plastic waste only pet coke in clinkerization. The toxic gas generation dioxin \& furan and other heavy metals during co-processing in cement kiln in comparison to the emission standards published by the MoEF\&CC.

Table 1:Stages of Study

\begin{tabular}{|l|l|l|}
\hline Stage-I & \multicolumn{3}{|l|}{$\begin{array}{l}\text { Sample collected 3km away from } \\
\text { dump site }\end{array}$} \\
\hline Soil Quality impact study & $\begin{array}{l}\text { Sample collected 3km away from } \\
\text { sea shore. }\end{array}$ & Sample collected at 2 meter from sea shore \\
\hline Stage-II & $\begin{array}{l}\text { Collection of sample of different } \\
\text { type of recycle number }\end{array}$ & $\begin{array}{l}\text { Shredding the sample and analysis of the sample } \\
\text { for the analysis }\end{array}$ \\
\hline $\begin{array}{l}\text { Analysis of gross calorific value of the type of recycle plastic number } \\
\text { Stage-III }\end{array}$ & $\begin{array}{l}\text { Analyze the fuel calorific value for } \\
\text { Specific heat comparison with and without } \\
\text { plastic waste in clinkerization }\end{array}$ & $\begin{array}{l}\text { Record the data of fuel consumed and record the } \\
\text { quantity of the product generated }\end{array}$ \\
\hline $\begin{array}{l}\text { Toxic gas emission analysis in comparison } \\
\text { with the emission standards }\end{array}$ & $\begin{array}{l}\text { Analysis of the stack emission as per the standard procedure as per the legal procedure or } \\
\text { guideline. }\end{array}$ \\
\hline
\end{tabular}

\section{METHODOLOGY}

The execution of the study will be implemented in the phase wise manner as per the scope of study obtained.

The execution of the dissertation is planned in following steps:

1. Analysis of the plastic waste impact on the soil and sea water quality. In this step the analysis will be carried out in which the impact of the weathered plastic will be identified. In this the heavy metal analysis will be carried out and that will be compared with the quality of soil available in that locality where there is no impact of plastic waste dumping.

2. Impacted soil sample will be collected from the dump yard of the municipality/nagar-palika and other sample will be collected $3 \mathrm{~km}$ meter away from the Landfill dump yard boundary.

3. Similarly, the sea sample will be collected from seashore about to 2 meter of the sea and other sample will be collected $3 \mathrm{~km}$ away from sea shore. 
4. Plastic waste sample of different recycle type will be collected to identify the gross calorific value respectively.

5. Than the data of calorific value of fuel and plastic waste and record the quantity of clinker production for the day leads to the calculation of specific heat consumption for the production of clinker in cement plant where this plastic waste co-processed as alternate fuel.

6. During co-processing of the plastic waste process emission pollutant will be analyzed by iso-kinetic sampling. This emission is analyzed at the raw mill\& kiln stack which is a main source of emission to analyze the impact of the emission in the quality of air in environment as per the legal framework standardization.

\subsection{PHASE-I: SOIL AND SEA WATER QUALITY ANALYSIS}

\section{Obtaining samples of Soil and Sea Water:}

Firstly, for the analysis of the plastic waste impact on the soil and water quality analysis was started in the study. In the sequence the study was conducted in the post monsoon season. The location of the dumpsite was selected in the talukaJafarabad, Gujarat. The population of the region as per the Indian Census 2011 is 27,167 persons. The dumping site is approx. $2-3 \mathrm{Km}$ away from the town center. The dump site is regularly leveled with the soil. The next sample is collected away from the dumpsite which is around $3 \mathrm{~km}$ distance.

Similarly, the sea water sample was collected 2 meter from the shore which is a possible source of plastic waste mixing to the sea by surface runoff. The normal sea water was collected from $3 \mathrm{~km}$ away from the sea shore.

First sample is collected from the dumpsite by digging at a depth of around 1.0 meter. This sample was also collected just like the sample collected from the dumpsite. The sample is collected individually in the both half kg plastic bags from both the locations.

Similarly, the sea water was collected near town at 20 meters from shore at a depth of 1.0 meter. The fresh sea water was collected $3 \mathrm{~km}$ away from the sea shore at a depth of 1.0 meter. Both the water sample was collected in the separate plastic bottle of 1.0 Liter.

The samples which are to be analyzed for heavy metals were preserved by adding $5 \mathrm{ml}$ nitric acid per liter of water sample.

Table 2: Analysis Parameters

\begin{tabular}{|l|l|l|}
\hline S. No. & Sample & Sample Parameters \\
\hline 1 & Soil & pH, Heavy metals $(\mathrm{Cd}, \mathrm{Ti}, \mathrm{Pb}, \mathrm{Co}, \mathrm{Cr}, \mathrm{Cu}, \mathrm{Mo}$ and $\mathrm{Zn})$, Potassium ,Nitrogen, Phosphorous, \\
\hline 2 & Water & Soil Water Heavy metals $(\mathrm{Cd}, \mathrm{Cu}, \mathrm{Co}, \mathrm{Cr}, \mathrm{Pb}, \mathrm{Mo}, \mathrm{Ti}$ and $\mathrm{Zn})$ \\
\hline
\end{tabular}

\section{Estimation of the Heavy Metals in sea water:}

- $200 \mathrm{ml}$ of water sample taken in conical flask digest it for organic substance, if any, with $20 \mathrm{ml}$ of conc. nitric acid in fuming chamber.

- The digested samples were made up to $20 \mathrm{ml}$ with $0.1 \mathrm{~N}$ HNO3 and analyse for $\mathrm{Cd}, \mathrm{Co}, \mathrm{Cr}, \mathrm{Cu}, \mathrm{Pb}, \mathrm{Mo}$, $\mathrm{Ti}$ and $\mathrm{Zn}$ with Atomic Absorption Spectrophotometer under following table conditions are mentioned

\section{Soil Sample Analysis}

Analysis Method: As Per EPA1311, ASTM D4980, EPA 3050B, and

Instruments Used: ICP-OES \& CHNS Analyser.

\section{Conclusion:}

- There was no significant difference in level of heavy metals in sea water samples as seen in case of soil samples. This may be due to dilution factor because of rainfall, high tide low tide, and wind speed and sea bottom current.

- Availability of phosphorous and potassium was found to be higher in control soil samples than dumpsite samples indicating the depletion of nutritional quality of dumpsite soil due to dumping of municipal solid waste,

- However, higher concentration of nitrogen and chloride ion was found in the soil of dumpsite area. The probable reason may be decomposition of landfilled/dumped waste under environmental conditions leading to formation of different characteristic chemical moieties viz, nitrogen, methane, chloride, phosphate etc.

- Accumulated dumped waste containing high plastic contents as well as soft soil profile of high infiltration capacity caused high organic and inorganic material holding.

\subsection{PHASE-II: Analysis of gross calorific value of the different type of recycle plastic number}

\section{Calorific analysis of the different type of plastic:}

-In this process firstly all the type of plastic is shredded in small size of pellets. Each type of plastic pieces is weigh in the weighing machine and note down the mass of different type of plastic. 
-Prepare the Bomb-calorimeter check the bath level of the bucket should be fill up to the distilled water can merge the bomb. The pressure in the oxygen cylinder should be checked so that no issues originate during analysis.

-Bomb should be properly clean. Firstly, unthread the pressure valve remove the cap of bomb, install the nickel chrome wire at the hanger such a way that it touches to the bottom of crucible.

-Place the crucible in the hanger touching wire. Thereafter close the lead and fill the compressed oxygen at the 400 psi and then tight the pressure valve. Than connect the bomb with the electrode and with help of clamp place in water bath. The electrode should be proper inserted in the bomb and close the bomb box cover.

Table 3: Result of gross calorific value

\begin{tabular}{|l|c|c|c|}
\hline S.No. & Type of Recycle & Type of Plastic & Gross Calorific Value(kCal/kg) \\
\hline 1 & 3 & PVC & 5873.3 \\
\hline 2 & 4 & LDPE & 11288.9 \\
\hline 3 & 6 & PS & 9203.5 \\
\hline 4 & 2 & HDPE & 11559.2 \\
\hline 5 & 7 & OTR & 9956.7 \\
\hline 6 & 1 & PET & 5680.5 \\
\hline 7 & 5 & PP & 10904.2 \\
\hline
\end{tabular}

\subsection{PHASE-III: SPECIFIC HEAT COMPARISON AND GASEOUS EMISSION ANALYSIS:}

Specific heat estimation while co-processing in cement plant:

\section{Preparation of the raw material of Plastic Waste:}

In this process a local supplier is identified who can supply the segregated waste plastic waste of desired size. In the requirement of feeding the plastic size should be $<50 \mathrm{~mm}$. This size will help in the equal heat distribution throughout the burning phase. This material is undergoing by process which is called as pre-treatment of the waste make it suitable in feeding. This pre-treatment of waste has following stages:

(i)Collection: In this method supplier collect all the waste from all around the town and transport it to the proper location, which is act as collection centre.

(ii)Sorting: In this process the segregation of the plastic waste is done from the rest of the waste and collects all the material at separate designation place. In this manual sorting or mechanized sorting is used.

(iii)Shredding: In this method the waste is feed in the hopper through a motorized conveyor (Screw conveyer cab be used) to a shredder. This shredder has sharp blades which rotate anti clock wise and tear the plastic waste in size below $50 \mathrm{~mm}$.

(iv)Transportation: In this phase all the shredded material is transported to the cement industries through trolleys and trucks. This is the phase where the cost of the fuel is incurred so if the pre-treatment facility is near to cement plant than the cost will be less.

\section{Co-processing of the plastic waste in Pre-heater:}

Feeding: In this stage the plastic waste with help of the front end loader feeded in the hopper from which the material is pass through belt conveyor to the feeding hopper at the calciner present in pre-heater. Hopper feed is controlled by the RAV (Rotary air lock valve) through which shredded plastic is fed in the Pre-heater which is above cement kiln.

Material Balance: The material to be fed in the kiln has to be access as to how much fuel we are able to replace by burning the plastic waste in the cement kiln.

- In the PC start the software and insert the mass of the sample and name of the sample and then click on start. The sample will burn and generate the heat so the calculated value of Calorific value is obtained.

- After completion of the analysis kindly clean the bomb and crucible for further future testing.

\section{Sampling of the Plastic Waste at Storage yard:}

- In this stage the waste is pre checked to identify that it is feasible in quality to be feed in the cement kiln.

- In general, this waste is composed of LDPE, HDPE, PET type of plastic which is ambient in generation and collection.

- Analysis is required to be done because the chlorine is a hindering parameter which causes scaling in the pre-heater due to which material stick at the cyclone of the pre-heater.

- $\quad$ The plastic sample approx. around $1.0 \mathrm{~kg}$ is collected cumulative from four different location of heap and send to laboratory for the analysis of parameter CV, Moisture, Chlorine.

- The plastic waste is fed in the Bomb calorimeter to analyse the calorific value of the waste. 
Table 4 Results of Fuel

\begin{tabular}{|c|l|c|c|c|c|}
\hline S.No. & Parameters & Unit & Plastic Analysis & Pet coke Analysis & Clinker Production (MT) \\
\cline { 1 - 5 } 1 & GCV & Kcal/Kg & 7850 & 7568 & \\
\cline { 1 - 4 } 2 & Size & Mm & $<50$ & $<1.0$ & 3465 \\
\hline 3 & Without (Plastic waste) & MT & - & 345 & 3351 \\
\hline 4. & With (Plastic waste) & MT & 10 & 324 & \multirow{2}{*}{} \\
\hline
\end{tabular}

\section{Calculation of Specific Heat without Co-processing:}

1.Total Calorific Value of Pet Coke $=2610960000$ KJ (Pet Coke calorific value $x$ Quantity consumed)

2.Specific heat $=2610960000 \mathrm{KCal} / 3465000 \mathrm{Kg}$ (Clinker)

3.Specific Heat $=753 \mathrm{kCal} / \mathrm{Kg}$ of Clinker

\section{Calculation of Specific Heat with Co-processing:}

1. Total Calorific Value of Fuel=245232000 KJ (Pet Coke calorific value x Quantity consumed) + 78500000 KJ (Plastic Waste calorific value $\mathrm{x}$ Quantity consumed)

2. Specific heat $=253532000 \mathrm{KCal} / 3351000 \mathrm{Kg}$ (Clinker)

3.Specific Heat $=755 \mathrm{kCal} / \mathrm{Kg}$ of Clinker

\section{STACK MONITORING TO STUDY THE IMPACT ON AIR QUALITY:}

The emission analysis was performed as per the Methods and Standard operation procedure of emission testing in hazardous waste incinerator published by the Central Pollution Control Board f September 2007 edition.

The major reason is the temperature in the cement kiln which is maintained around $1300^{\circ} \mathrm{C}$ due to which all the complex and toxic chemicals are break down into simpler compound which lead to be a good disposal method. As the dioxin furan are the most harmful gases generated into by burning plastic waste but in monitoring of emission concentration was $0.019 \mathrm{ngTEQ} / \mathrm{Nm} 3$ as compared to standard of $0.1 \mathrm{ngTEQ} / \mathrm{Nm} 3$.

Table 5 Stack Monitoring analysis report

\begin{tabular}{|l|l|l|l|l|}
\hline S.No. & Parameters & Unit & Standard & Analysis \\
\hline 1 & $\mathrm{PM}$ & $\mathrm{mg} / \mathrm{Nm} 3$ & 30 & 4.2 \\
\hline 2 & $\mathrm{SO} 2$ & $\mathrm{mg} / \mathrm{Nm} 3$ & 100 & 7.17 \\
\hline 3 & $\mathrm{NO} 2$ & $\mathrm{mg} / \mathrm{Nm} 3$ & 800 & 412.3 \\
\hline 4 & $\mathrm{HCl}$ & $\mathrm{mg} / \mathrm{Nm} 3$ & 10 & 3.91 \\
\hline 5 & $\mathrm{HF}$ & $\mathrm{mg} / \mathrm{Nm} 3$ & 1 & $\mathrm{ND}$ \\
\hline 6 & $\mathrm{TOC}$ & $\mathrm{mg} / \mathrm{Nm} 3$ & 10 & 2.8 \\
\hline 7 & $\mathrm{Hg}$ and its compounds & $\mathrm{mg} / \mathrm{Nm} 3$ & 0.05 & $\begin{array}{l}\text { BLQ } \\
\text { (LOQ 0.005) }\end{array}$ \\
\hline 8 & $\mathrm{Cd}+\mathrm{Tl}$ and their compounds & $\mathrm{mg} / \mathrm{Nm} 3$ & 0.05 & 0.02 \\
\hline 9 & $\begin{array}{l}\text { Sb+As+Pb+Co+Cr+Cu+Mn+Ni+V and their } \\
\text { compounds }\end{array}$ & $\mathrm{mg} / \mathrm{Nm3}$ & 0.5 & 0.07 \\
\hline 10 & Dioxins and Furans & ngTEQ/ Nm3 & 0.1 & 0.0019 \\
\hline
\end{tabular}




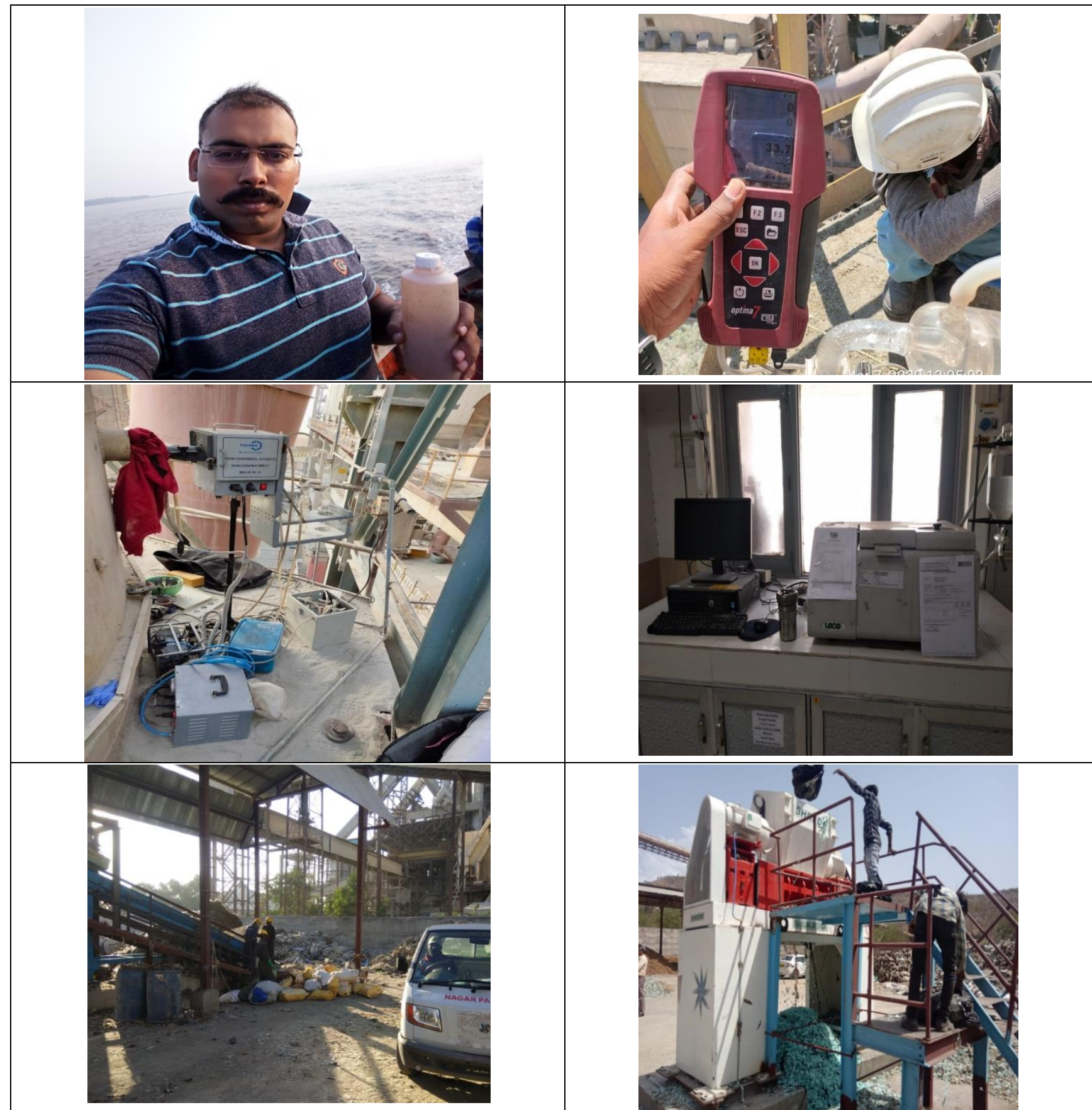

Fig. 2 Plastic Waste study glimpse

\section{CONCLUSION}

When impact of plastic waste analysed at the landfill of plastic waste in Jafarabad taluka of Gujarat. It shows that due to dumping of plastic waste phosphorous and potassium was found to be higher in normal soil samples than dumpsite samples which shows the depletion of nutritional quality of dumpsite soil due to dumping of waste

However, there was higher concentration of nitrogen and chloride ion was found in the soil of dumpsite area. The probable reason may be decomposition of landfilled/dumped waste under environmental conditions leading to formation of different characteristic chemical properties viz, nitrogen, methane, chloride, phosphate etc.

Accumulated dumped waste containing high micro plastic contents as well as soft soil profile of high infiltration capacity caused high organic and inorganic material holding.

It has been observed that dumping of plastic waste may deteriorates soil and water quality of sea due to leaching of additives, colours, stabilizes and fillers present in the different categories of plastic products. It is therefore suggested dependency on dumping of plastic waste should be reduced to preserve the soil and water quality of Environment. 
There was no significant difference in level of heavy metals in sea water samples as seen in case of soil samples. This may be due to dilution factor because of rainfall, high tide low tide, and wind speed and sea bottom current.

The recycle waste number 1 and 3 as per data are possessing calorific value lesser than other recycle number but still the values are closer to the calorific value of coal.

Calculation of specific heat through co-processing shows that with co-processing specific heat somewhat goes high around 755 $\mathrm{kCal} / \mathrm{kg}$ of clinker as compared without co-processing $753 \mathrm{kCal} / \mathrm{kg}$ of clinker which means the specific heat will require more to form clinker in cement plant. Even though the heat requirement is not altered that much so this shows that there is a scope of plastic waste to replace pet coke in manufacturing of clinker in cement plant.

Analysis of air quality through stack emission also clarified that if the plastic waste is burn in cement kiln than the emission so generated will be within the prescribed norms of co-processing as per the CPCB/MoEF\&CC emission standards.

The major reason is the temperature in the cement kiln which is maintained around $1300^{\circ} \mathrm{C}$ due to which all the complex and toxic chemicals are break down into simpler compound which lead to be a good disposal method. As the dioxin furan are the most harmful gases generated into by burning plastic waste but in monitoring of emission concentration was $0.019 \mathrm{ngTEQ} / \mathrm{Nm} 3$ as compared to standard of $0.1 \mathrm{ngTEQ} / \mathrm{Nm} 3$.

Waste plastic co-processing in cement kiln will be of tremendous shift change in waste management scenario in the country. The Indian cement industry one of the leaders in energy efficiency in the world is also moving towards Alternate fuel utilization. This co-processing waste will solve the dual problems of effective waste management as well as reduction in overall carbon emissions.

\section{REFERENCES}

[1]. MoEF\&CC (Plastic waste management rule 2016) and CPCB monitoring guideline from website cpcb.nic.in.

[2]. Study report 2014-CPCB and IITR Lucknow study on "Impact of plastic waste disposal on soil and water quality at Lucknow dumpsite"..

[3]. Guideline of Co-processing of Hazardous and other waste of CPCB-2017.

[4]. Jambeck, J. R., Geyer, R., Wilcox, C., Siegler, T. R., Perryman, M., Andrady, \& Law, K. L. (2015) generation of plastic.

[5]. Harald Pilz, Bernd Brandt, Roland Fehringer (2010) The impact of plastics on life cycle energy consumption and greenhouse gas emissions in Europe retrieve from www.empa.ch/lca.

[6]. Pilz, H., Schweighofer, J. \& Kletzer, E. (2005): The Contribution of Plastic Products to Resource Efficiency, PlasticsEurope - Association of Plastics Manufacturers, Brussels, Belgium.

[7]. Paolo Fornaseri (2014) Plastic Waste Handling and its Influence on Household Waste Incineration. Retrieve from www.diva-portal.org.

[8]. IDBEF.ORG (Report 2020): Indian Cement Industry Analysis retrieves from https://www.businesswire.com/

[9]. Arif Setyo (2018). Plastic waste as an alternative energy. Retrieve from https://aip.scitation.org/

[10]. Hanna Ritchie and Max Roser (2018). Plastic Pollution. Retrieve from https://ourworldindata.org/ 